\title{
当院における高令者の骨折について
}

国立三朝温泉病院整形外科

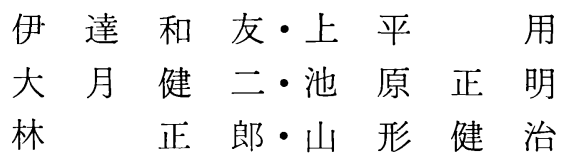

\section{A Clinical Observation of the Fractures in Aged Patients}

by

\author{
K. Date, M. Kamihira, K. Ohstuki, M. Ikehara, \\ M. Hayashi and K. Yamagata \\ Department of Orthopaedic Surgery, \\ Misasa Onsen National Hospital
}

\begin{abstract}
34 cases of the fractures of long bone in patients (over 70 year-old) were experienced for recent four years.

They consisit of fractures of femur (27 cases), humerus (5 cases) and tibia (2 cases).

The methods of operative treatment, pre and post operative complications were discussed with regard to early movilization.
\end{abstract}

人口の老令化に伴い高令者の骨折は増加する傾向に ある.しかむ，術前術後に問題のあるととが多く，治 療に難渋することが少なくない．

われわれは, 観血的治療を行った 70 才以上の長管 骨々折について, 治療法及び術前術後の合併症を検討 し，若干の知見を得たので報告する.

\section{対象と治療法}

\section{1. 対象}

昭和 51 年 4 月以後, 当院において観血的治療を行 った長管骨々折は 95 例で, そのうち 70 才以上の 34 例（37 手術）を対象とした. 性別発生頻度は男性 12 例，女性 22 例であった.

骨折部位は大腿骨頸部内側骨折が 9 例, 転子部骨折 16 例, 骨幹部骨折 2 例, 上腕骨々折 5 例及び脛骨々 折が 2 例であった. そのうち, 初診時新鮮骨折は 28 例 (30 手術), 偽関節形成等は 6 例 ( 7 手術) であっ た。 なお多発性骨折む 2 例に認められ，1例は大腿骨 頸部内側骨折と Colles 骨折, 他は大腿骨転子部骨折 と坐骨々折を合併していた.
長管骨々折のうち, 多くを占めた大腿骨頸部内側骨 折，転子部骨折をそれぞれ Garden 分類，Evans 分 類により分けた. 頸部内側骨折では stage 2 (4 例), stage 3 (2 例) が比較的多く, また, 転子部骨折に おいては type 1 の group 1 が 7 例, group 2 が 4 例で, 両者で過半数を占めていた（表 1 ).

\section{2. 治療法}

受傷より 初回手術までの 期間は最短 4 日, 最長 14 カ月で 7 日前後に手術されたものが最っとも多かっ た.

治療法の詳細は表 1 に示しているが, 大腿骨頸部内 側骨折に扰いては，大ネジ固定法が stage 1，2，3， にそれぞれ 1 例ずつ, 人工骨頭置換術は stage 2 に 対して 2 例, stage 3，4，上偽関節に対しそれぞれ 1 例ずつ試みられた。 また，転子部骨折においては，大 ネジ固定術は type 1 の group 1 (6例) と group 2 (2 例) 飞比較的多く施行され, Jewett nail plate 固定術はいずれの type にあ施行された.なお，再手 術例は Jewett nail plate 固定法の type 1 group と type 2 の遷延治癋例であり, 前者では同法による 
表 1 大腿骨頸部骨折の分類と治療法

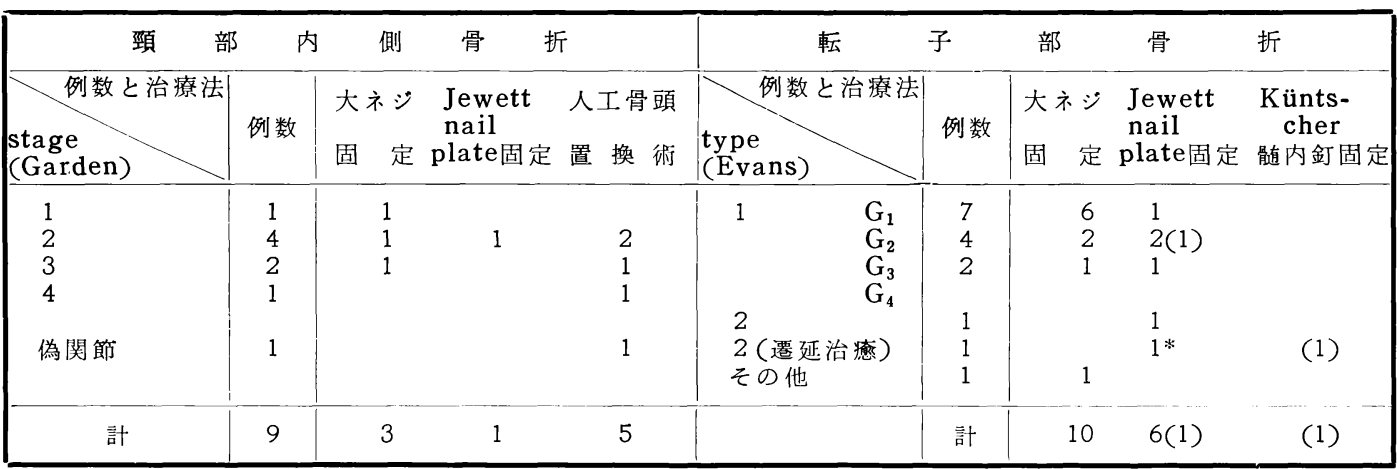

（）再手術例の再掲＊骨移植術併用

再固定術, 後者では Küntscher 䯣内釘固定法 が施 行された.

上腕骨の外科頸骨折（2 例）に対しては, ネジ固定 術と plate 固定術がそれぞれ 1 例, 骨幹部骨折 (2 例）に対してはネジ固定術と plate 固定術がそれぞ れ 1 例, 顆上骨折（1例）にはネジ固定法が施行され た. そのうち, 骨幹部骨折のネジ固定例では再手術 (plate 固定術之骨移植術) が試みられた.

脛骨々幹部骨折（2 例）に対してはともに plate 固定術が行われた.

\section{3. 麻酔法と出血量}

34 例 37 手術に対し，気管内挿管またはマスクによ る全身麻酔が 22 手術（大腿骨々折 16 手術, 上腕骨々 折の 6 手術）に，腰椎麻酔が 9 手術（大腿骨々折の 7 手術, 脛骨々折の 2 手術）に試みられた。 また，局所 麻酔も大腿骨転子部骨折の大ネジ固定法の 6 手術に施 行された.

手術時平均出血量を骨折部位別にみると, 大腿骨頸 部内側骨折においては $444 \mathrm{ml}$ (人工骨頭置換術で576 $\mathrm{ml}$ ，骨接合術で $138 \mathrm{ml}$ )，転子部骨折では $262 \mathrm{ml}$ あった．上腕骨々折においては，外科頸骨折で 427 $\mathrm{ml}$, 骨幹部骨折で $275 \mathrm{ml}$, 顆上骨折で $370 \mathrm{ml}$ であ り,また, 脛骨々折では $215 \mathrm{ml}$ 出血した.

\section{結果}

\section{1. 術前合併症}

同一患者で重複合併症を有するあのが多い，主な合 併症はのべ 41 症例であり，高血圧症 9 例，右脚ブロ ック 7 例等心疾患が 26 症例に達しもっとも多く, 次 いで慢性関節リウマチ，片マヒ，癌がそれぞれ 3 症
表 2 術前合併 症

\begin{tabular}{|c|c|}
\hline $\begin{array}{l}\text { 心疾患 } \\
\text { 高血圧症 } \\
\text { 右脚ブロック } \\
\text { 上室性期外収縮 } \\
\text { 心房細動 } \\
\text { 心筋硬塞 } \\
\text { その他 } \\
\text { 慢性関節リウマチ } \\
\text { 片マヒ } \\
\text { 癌前立腺肥大症 } \\
\text { その他 } \\
\text { 計 }\end{array}$ & $\begin{array}{l}26 \text { 例 } \\
9 \text { 例 } \\
7 " \prime \\
4 \prime \prime \\
2 \prime \prime \\
2 \prime \prime \\
2 " \\
3 \text { 例 } \\
3 \prime \prime \\
3 \prime \prime \\
2 \prime \prime \\
4 \prime \prime \\
41 \text { 例 }\end{array}$ \\
\hline
\end{tabular}

例，前立腺肥大症 2 症例等の順であった（表 2 ）.

\section{2. 術後合併症}

術中, 術後麻酔による 直接の 副作用は認めなかっ た。

術後全身合併症としては尿路感染症が 4 例, 老人性 痴呆 3 例, 褯創形成 3 例, 肺炎が 1 例であり, 術後 6 カ月以内の死亡は 2 例であった。 乙れらの合併症はす べての大腿骨頸部骨折に認められ，手術々式との間に は相関々係はみいだし得なかった，死亡の 1 例は食欲 低下による全身衰弱のため死亡し，他の 1 例は直接の 死因は不明であった.

局所合併症として，1〜2例において表在的な創の 遷延治癒がみられたが，化膿等の重篤な合併症は認め られなかった。

大腿骨頸部骨折以外の X 線学的骨癒合は 1 例（上腕 骨）にて変形治癒の傾向がみられたが，他はすべて最 終的にはほぼ解剖学的に治瘉した.

\section{3. 大腿骨頸部骨折の治療成績之症例検討}

比較的多く経験した老人の大腿骨頸部骨折を中心に 
調査した.

70 才以上の高令者の発生平均年令は内側骨折が 76.5 才に対し，転子部骨折は 80.2 才でより高年令層 に発生する傾向がみられた。

大腿骨頸部骨折 25 例中アンケート調査を含め 19 例 を追跡調査し得た。

介助の要, 不要, 更に杖使用の有無, 車椅子の使用 並びにベット上での生活か否か等の日常生活面より調 查した，大腿骨顓部内側骨折に対して人工骨頭置換術 を行い得た症例では, 早期離床が可能となったため比 較的良い結果が得られた. 術前より片マヒ, 慢性関節 リウマチ等の合併症を持与日常生活を制限されていた 症例等全身状態が悪いものでは, 理想とする治療法を 選択するととができず，比較的侵襲の少ない大ネジ固 定術に終ったため, 術後に介助を要するあのも多かっ た（表 $3 ）$.

表 3 大腿骨形部骨折の治療成績

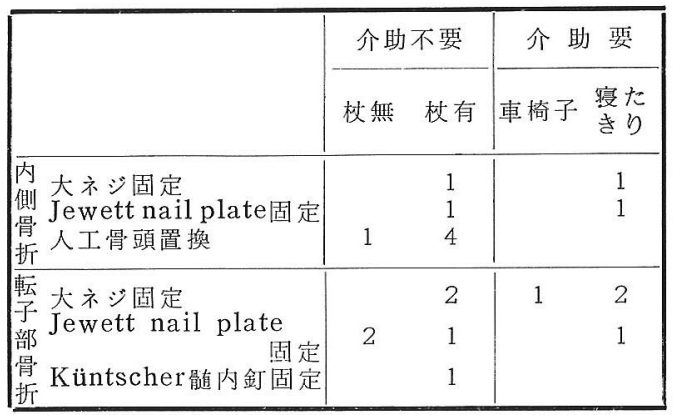

再手術を含めた最終的な X線学的後遺症として, 内 側骨折にては骨接合術 4 例中内反変形が 1 例（大ネジ 2 本固定), nail 先端の骨頭よりの突出が 1 例 (Jewett nail plate 法)にみられた，転子部骨折にては 16 例の骨接合術中内反変形が 3 例（大ネジ固定的 2 例, Jewett nail plate 法 1 例), 遷延治瘑が 1 例 （大ネジ 3 本固定）に認めら机た。

また, 内側骨折の人工骨頭置換術 5 例中 1 例飞異所 性骨化が発生した.

次に，興味ある 3 症例について述べる.

症例 179 才 女性

左片マヒのため入院治療中転倒し歩行困難となり受 診した. Garden 分類の stage 3 に相当し（図 1, A), 受傷 10 日後人工骨頭置換術を行った（図 1 , B), 術後早期に機能訓練を再開し，1 本杖歩行で 退
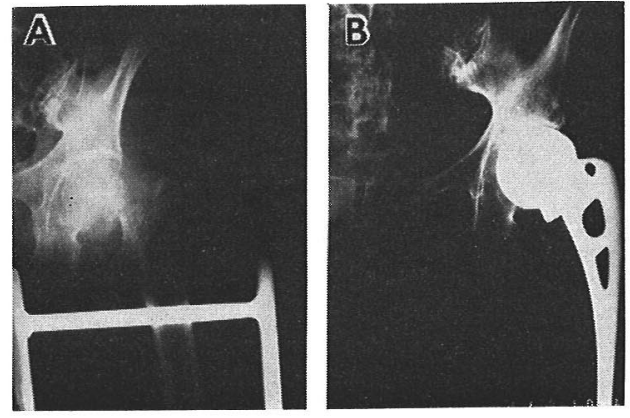

図 1

院した.

症例 271 才 女性

慢性関節リウマチと梼尿病に罹患し，日常生活は空 内に限定さ机ていた。

自宅で転倒し歩行不能となり来院した．受傷直後の X線像では骨折線は不明であったが，臨床症状より頸 部内側骨折 Garden 分類の stage 2 と考えられス ピート牽引を行った（図2, A)。10日後の X 線像 で骨転位が確認されたため (図 2，B), Jewett nail plate 固定術が施行された (図 $2, C$ ). 現在, 骨折 部の骨癒合は良好であるが，骨頭より plate 先端の 突出が認めら机る．前述の既応症のため全身状態が悪 く，臥床したままである。
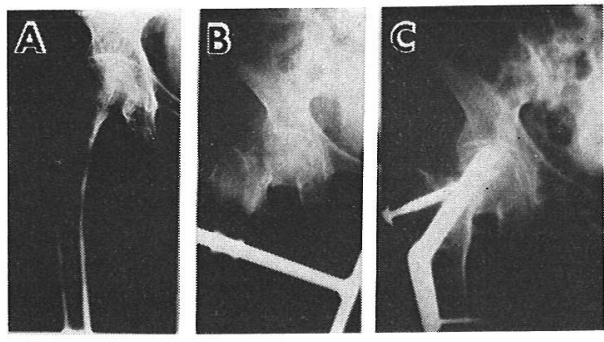

図 2

\section{症例 383 才 女性}

左片マヒ患者であり, 路上で転倒し歩行不能となり 来院した. X 線像にて Evans 分類の type 1 group 2 の左大腿骨転子部骨折が認められたため（図 3 ,

A) . 2 力月後の X 線像にて, ネジの破損之内反変形 が認められたので（図 3，C), Jewett nail plate の入れ替光を試みた。術後の骨癒合は順調であり（図 3，D)，現在ベット上での生活が可能である. 

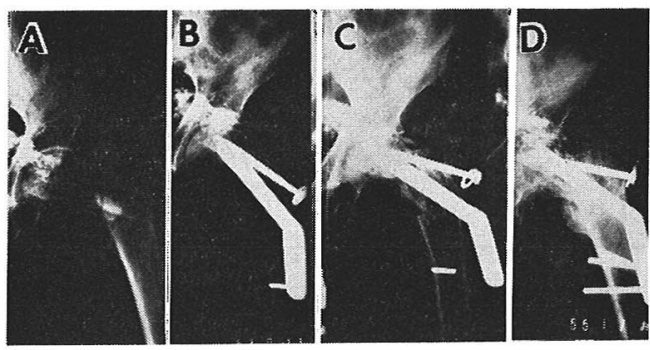

図 3

$$
\text { 考 }
$$

察

高令者の骨折，特に下肢の場合長期臥床による合併 症の予防のため早期離床が可能な治療を要求される。

少なくとも骨折前の全身状態にもたらす努力が必要で ある。

われわれもとの目的のため早期観血的治療を多く施 行してきた，特に老人に多い大腿骨頸部骨折に対して あ各種の観血的療法を試みているが，な打相当数の合 併症を認めた。

これらは，1) 術前の各種の合併症により，麻酔法 の制限を受ける結果, 理想的な手術法を選択ですず比 較的侵襲の少ない2 3 本の大ネジ固定法を行わざる を得なかったこと，2）かりに強固な内固定を行い得 ても老人性骨菱縮あるいは片マヒによる内転位拘縮の ため期待どおりの骨癒合がみられないととなどが主な 原因と考えられる.

それゆえに, 70 才以上の高令者の大腿骨内側骨折で は, 偽関節や Garden 分類の stage 4 のみならず, stage 3，2 の症例でも早期離床の必要性があるあの は, 全身状態が許す限り人工骨頭置換術を，その他の むのは骨接合術を施行し, 転子部骨折では stable type, unstable type を問わず, 可能な限り強固な 内固定を行い，早期離床を試みるととが，老人性痴杲 等の重篤な合併症子防ひいては延命のため重要である と考える.

また，特に老人外科においては，術前加ら術後を通 じて, 慎重なコントロールが要求されるため, 各科と のチームワークの必要性が痛感される.
結語

過去 4 年間に当院にて経験した 70 才以上の高令 者 の長管骨々折 34 例 37 手術について術前, 術後の合併 症, 治療法並びに治療成績を検討し, 次の結論を得 た.

1. 高令者に多い大腿骨頸部骨折のうち, 内側骨折 において, 人工骨頭置換術を行い得た症例では, 早期 離床が可能となり，良い結果となった，内側骨折のみ ならず転子部骨折においても，術前合併症のため全身 状態が悪く, 大ネジ固定術に終った例では, 術後介助 を要する不満足な結果のものが多かった．

2. 高令者の大腿骨内側骨折に扔いては, 偽関節や Garden 分類の stage 4 のみならず, stage 3, 2 に対しても人工骨頭置換術を行い，また，転子部骨折 そ拉いては, Evans 分類の stable type, unstable type を問わず，できるだけ強固な内固定を施行し， 早期離床をはかる必要がある.

3. 大腿骨頸部骨折に限らず, 老人の長管骨々折, 特に下肢の場合には, 強固な内固定法を施行し, 早期 離床をはかり，老人性痴呆等の合併症を防止すべきで ある.

\section{文献}

1）五十嵐三都男 - 他：纹害医学，18，203，1975。

2) Evans, E. M.: J. Bone Joint Surg., 33-B, 192, 1951.

3) Garden, R. S.: J. Bone Joint Surg., 46-B, 630, 1964.

4) 林 正郎 - 他：整形外科と災害外科， $28 ， 443$, 1980.

5）上平用・他：䠦整外，6，807，1971.

回答国立三朝 上平用

大腿骨頭部骨折に対し，大亦涸定の場合， $2 \sim 3$ 本使用しているが，片マヒと同側の骨折の場合，内反 変形をきたしよくない症例もみられた。

回 答国立三朝温泉病院 伊達 和友 術前より動脈硬化もともない, 術後早期離床をめざ したが老人性痴呆に到ったと考えられます. 